\title{
A novel biosensor based on the direct electrochemistry of horseradish peroxidase immobilized in the three-dimensional flower-like $\mathrm{Bi}_{2} \mathrm{WO}_{6}$ microspheres
}

\author{
Hui Liu ${ }^{*}$, Kai Guo ${ }^{\text {a }}$, Congyue Duan ${ }^{\text {a }}$, Xianjin Chen and Zhenfeng Zhu \\ *School of Materials Science and Engineering, Shaanxi University of Science and Technology \\ Xi'an 710021, P. R. China
}

\begin{abstract}
Three-dimensional flower-like $\mathrm{Bi}_{2} \mathrm{WO}_{6}$ microspheres (3D- $\mathrm{Bi}_{2} \mathrm{WO}_{6} \mathrm{MSs}$ ) have been synthesized through a simple hydrothermal method. The morphology and structure of 3D$\mathrm{Bi}_{2} \mathrm{WO}_{6}$ MSs were characterized by scanning electron microscopy (SEM) and X-ray diffraction (XRD). The 3D-Bi $\mathrm{WO}_{6} \mathrm{MSs}$ subsequently were used to immobilize horseradish peroxidase (HRP) and fabricate a mediator-free biosensor for the detection of $\mathrm{H}_{2} \mathrm{O}_{2}$. Spectroscopic and electrochemical results reveal that $3 \mathrm{D}-\mathrm{Bi}_{2} \mathrm{WO}_{6} \mathrm{MSs}$ constitute an excellent immobilization matrix with biocompatibility for enzymes. Meanwhile, due to unique morphology of the flower-like microspheres, the direct electron transfer of HRP is facilitated and the prepared biosensors display good performances for the detection of $\mathrm{H}_{2} \mathrm{O}_{2}$ with a wide linear range, including two linear sections: $0.5 \sim 100 \mu \mathrm{M}\left(\mathrm{R}^{2}=0.9983\right)$ and $100 \sim 250 \mu \mathrm{M}$ $\left(\mathrm{R}^{2}=0.9981\right)$, as well as an extremely low method detection limit of $0.18 \mu \mathrm{M}$.
\end{abstract}

Keywords: Biosensor, Enzyme immobilization, $\mathrm{Bi}_{2} \mathrm{WO}_{6}$, Three-dimensional flower-like microspheres, hydrogen peroxide

\footnotetext{
${ }^{*}$ Corresponding author. Tel: +86-29-86177018; Fax: +86-29-86177018.

Email address: liuhui@sust.edu.cn (H. Liu),

a These authors contributed equally to this work.
} 


\section{Introduction}

Recent researches show that nanomaterials modified electrode has special effect on electrocatalysis and electrochemical determination [1-4]. Especially in system contained many kinds of similar substrate, some electrodes have selective detection or simultaneously detection [5-8]. Meanwhile, nanomaterial can play an important and unique role in direct electrochemical biosensor [9-14]. The researches of direct electron trsansfer (DET) of enzymes or redox proteins can not only help to understand the intrinsic kinetic and thermodynamic properties of proteins but also establish a foundation for fabricating mediatorfree biosensors $[15,16]$. However, it is difficult for proteins to realize the DET process on the bare electrode, due to the deep burying of electroactive center in the protein structure and the denaturation of proteins on the bare electrode surface $[17,18]$. Recent studies show that a series of nanomaterials with good biocompatibility and special surface effect can be used to immobilize enzymes and fabricate mediator-free biosensors [18, 19]. Among them, threedimensional (3D) structured nanomaterials, such as 3D nanostructured $\mathrm{NiO}$ [19], $\mathrm{ZnO}$ [20], $\mathrm{TiO}_{2}$ [21], $\mathrm{MnO}_{2}$ [17] microspheres and $\mathrm{Co}(\mathrm{OH})_{2}$ macroporous film [22], have received increasing attention for their unique structure and morphology. It has been shown that the structure and morphology of nanomaterials have a significant effect on the property of the immobilized enzyme, which determines their efficacy in biosensors [23]. So finding new nanomaterials with special morphology and structure possessing high biosensor performance is still a challenge.

To the best of our knowledge, 3D structured $\mathrm{Bi}_{2} \mathrm{WO}_{6}$ nanomaterial as a support for constructing mediator-free biosensor has rarely been reported. Here, three-dimensional flower-like $\mathrm{Bi}_{2} \mathrm{WO}_{6}$ microspheres $\left(3 \mathrm{D}-\mathrm{Bi}_{2} \mathrm{WO}_{6} \quad \mathrm{MSs}\right.$ ) were synthesized by a simple hydrothermal method. This kind of $3 \mathrm{D}-\mathrm{Bi}_{2} \mathrm{WO}_{6} \mathrm{MSs}$ possess many advantages as a support for immobilization of enzyme. As shown in Scheme 1, numerous nanosheets, all pointing toward the center of the sphere, constitute the $3 \mathrm{D}-\mathrm{Bi}_{2} \mathrm{WO}_{6} \mathrm{MSs}$ which own a large surface area available for enzyme entrapment. And the trumpet-shaped pores among the nanosheets 
can become tunnels to the interior of the microsphere for enzymes. Furthermore, the nanosheets are formed from numerous smaller nanosheets (less than $100 \mathrm{~nm}$ in length) which can greatly enhance the active surface area for adsorbing enzymes (Fig. S1). Meanwhile, the substrate has easy access to the enzymes immobilized in the microspheres through the trumpet-shaped pores. Concentration of substrate and enzyme in this confined region will increase the chance of effective collisions between them [24]. Hence, such kind of 3D$\mathrm{Bi}_{2} \mathrm{WO}_{6} \mathrm{MSs}$ are able to become a promising support for enzyme immobilization and have potential applications in biosensors.

In this study, horseradish peroxidase (HRP) is selected as a model redox protein for construction of the biosensor. Meanwhile, to highlight the advantages of the $3 \mathrm{D}-\mathrm{Bi}_{2} \mathrm{WO}_{6} \mathrm{MSs}$, Bi2WO6 nanoparticles $\left(\mathrm{Bi}_{2} \mathrm{WO}_{6} \mathrm{NPs}\right)$ are also used as a support to immobilize HRP.

\section{Experimental}

\subsection{Materials and apparatus}

HRP and Nafion were purchased from Sigma (St. Loius, MO, USA). Other chemical reagents were purchased from Sinopharm Chemical Reagent Co., Ltd., China. All reagents are analytical grade. In all experiments, deionized water was used.

Field-emission scanning electron microscopy (FE-SEM) was performed using a Hitachi S4800 \& Hiroba energy dispersive X-ray electron miscroscope (Hitachi, Japan). X-ray diffraction (XRD) patterns were recorded on a Rigaku D/max 2200pc diffractometer (Rigaku, Japan) using $\mathrm{Cu} \mathrm{K} \alpha$ radiation of wavelength $\lambda=0.15418 \mathrm{~nm}$ at $40 \mathrm{kV}$ and $40 \mathrm{~mA}$. UV-vis spectra were recorded using a PerkinElmer Lambda-950 spectrophotometer (PerkinElmer, America). FT-IR spectra were obtained on a Bruker TENSOR27 instrument (Bruker, Germany). Zeta potential was performed by a Malvern Nano-Z system (Malvern, England). All electrochemical experiments were performed with a CHI 660E electrochemical workstation (CH Instruments, China). A conventional three-electrode system, which consisted of a platinum wire as the counter electrode, an $\mathrm{Ag} / \mathrm{AgCl} / 3 \mathrm{M} \mathrm{KCl}$ as the reference electrode and a 3-mm diameter modified glassy carbon electrode (GCE) as the working electrode, was 
used in all electrochemical experiments. Unless otherwise noted, $0.1 \mathrm{M}$ phosphate buffered saline (PBS; $\mathrm{pH} 7.0$ ) was used as the supporting electrolyte in all experiments. The buffer was purged with highly purified nitrogen for at least $30 \mathrm{~min}$ and a nitrogen atmosphere environment was kept in electrochemical measurements.

\subsection{Synthesis of 3D-Bi ${ }_{2} \mathrm{WO}_{6}$ microspheres}

The $3 \mathrm{D}-\mathrm{Bi}_{2} \mathrm{WO}_{6}$ microspheres were synthesized by a facile hydrothermal reaction. In a typical synthesis, the starting materials of $\mathrm{Na}_{2} \mathrm{WO}_{4} \cdot 2 \mathrm{H}_{2} \mathrm{O}$ and $\mathrm{Bi}\left(\mathrm{NO}_{3}\right)_{3} \cdot 5 \mathrm{H}_{2} \mathrm{O}$ with the stoichiometric ratio were added into $30 \mathrm{~mL}$ deionized water with stirring for $10 \mathrm{~min}$, respectively. Then the $\mathrm{Na}_{2} \mathrm{WO}_{4} \cdot 2 \mathrm{H}_{2} \mathrm{O}$ solution was added with drop by drop to the $\mathrm{Bi}\left(\mathrm{NO}_{3}\right)_{3} \cdot 5 \mathrm{H}_{2} \mathrm{O}$ suspension. After stirring for $30 \mathrm{~min}$, the obtained white suspension was loaded into a $100 \mathrm{ml}$ Teflon-liner autoclave and then treated for $12 \mathrm{~h}$ at $180^{\circ} \mathrm{C}$. The products were washed with deionized water and absolute ethanol to remove any ionic residue then dried at $60^{\circ} \mathrm{C}$.

\subsection{Preparation of enzyme electrode}

Prior to use, a glassy carbon electrode (GCE) was polished with 0.3 and $0.05 \mu \mathrm{m}$ alumina slurry and sonicated in ethanol and water successively. The cleaned GCE was dried using a purified nitrogen stream. The enzyme electrode was prepared by a simple casting method.

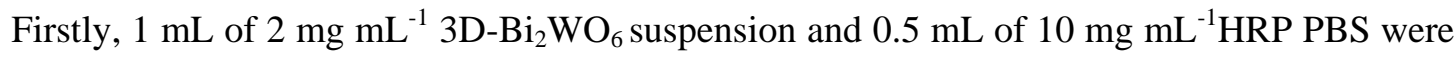
mixed and stirred for $20 \mathrm{~min}$. Secondly, $0.5 \mathrm{~mL}$ of Nafion (5\%) was added to the mixture and then stirred for $10 \mathrm{~min}$. Finally, $4 \mu \mathrm{L}$ of the mixture was applied to the surface of a freshly polished GCE to prepare the Nafion/HRP/3D- $\mathrm{Bi}_{2} \mathrm{WO}_{6} / \mathrm{GCE}$ and then stored in refrigerator prior to use. To compare, $\mathrm{Bi}_{2} \mathrm{WO}_{6}$ nanoparticles $\left(\mathrm{Bi}_{2} \mathrm{WO}_{6} \mathrm{NPs}\right)$ were used for the fabrication of Nafion/ $/ \mathrm{HRP} / \mathrm{Bi}_{2} \mathrm{WO}_{6} \mathrm{NPs} / \mathrm{GCE}$ with similar procedures as described above. In the control experiment, Nafion/HRP/GCE and Nafion/3D- $\mathrm{Bi}_{2} \mathrm{WO}_{6} / \mathrm{GCE}$ were also prepared. Before electrochemical measurements, all the as-prepared film electrodes were immersed in $\mathrm{pH} 7.0$ PBS for 30 min to remove residual components.

\section{Results and discussions}




\subsection{Characterization of $3 \mathrm{D}-\mathrm{Bi}_{2} \mathrm{WO}_{6} \mathrm{MSs}$}

$\mathrm{X}$-ray diffraction (XRD) is firstly used to determine the structure and crystallinity of the asprepared products. Fig. 1 shows the XRD pattern of the products. The peaks in this diffraction pattern correspond to the orthorhombic $\mathrm{Bi}_{2} \mathrm{WO}_{6}$ crystal phase (JCPDS No. 73-2020). The XRD pattern also indicates that the prepared $\mathrm{Bi}_{2} \mathrm{WO}_{6}$ sample has a high crystallinity.

As shown in Fig. $2 \mathrm{~A}$ and $\mathrm{B}$, the $3 \mathrm{D}-\mathrm{Bi}_{2} \mathrm{WO}_{6} \mathrm{MSs}$ with the diameter of about $4 \mu \mathrm{m}$ are composed of numerous nanosheets pointing toward the center of the sphere. The trumpetshaped pores among the nanosheets can become tunnels to the interior of the microsphere for enzymes. Furthermore, from the higher-magnification SEM image (the inset of Fig. 2B), the nanosheets are formed from numerous smaller nanosheets (less than $100 \mathrm{~nm}$ in length). This special structure can greatly enhance the active surface area for enzymes adsorption.

Fig. $2 \mathrm{C}$ depicts the microstructure image of Nafion/HRP/3D- $\mathrm{Bi}_{2} \mathrm{WO}_{6}$ composite film. It is noted that $3 \mathrm{D}-\mathrm{Bi}_{2} \mathrm{WO}_{6} \mathrm{MSs}$ is discernible on the surface of modified electrode. The $3 \mathrm{D}$ $\mathrm{Bi}_{2} \mathrm{WO}_{6} \mathrm{MSs}$ is embedded in the Nafion to form a stable composite film which is essential for the stability of the prepared enzyme electrode. Moreover, because of the high surface area of $3 \mathrm{D}-\mathrm{Bi}_{2} \mathrm{WO}_{6} \mathrm{MSs}$, the effective surface area of the modified electrode improves greatly (Fig. 2D).

Fig. S1 gives the typical SEM images of 3D- $\mathrm{Bi}_{2} \mathrm{WO}_{6} \mathrm{MSs}(\mathrm{A})$ and $\mathrm{HRP} / 3 \mathrm{D}-\mathrm{Bi}_{2} \mathrm{WO}_{6} \mathrm{MSs}$ (3D- $\mathrm{Bi}_{2} \mathrm{WO}_{6} \mathrm{MSs}$ immobilizing HRP) (B).It can be clearly seen from the comparison that the special three-dimensional flower-like structure and the rough surfaces of $\mathrm{Bi}_{2} \mathrm{WO}_{6}$ microspheres can greatly enhance the active surface area for enzymes adsorption.

\subsection{Encapsulation of $\mathrm{HRP}$ in the of $\mathrm{Nafion} / 3 \mathrm{D}-\mathrm{Bi}_{2} \mathrm{WO}_{6}$ composite film}

Zeta potential measurement shows that the prepared $3 \mathrm{D}-\mathrm{Bi}_{2} \mathrm{WO}_{6} \mathrm{MSs}$ carry negative charges with a zeta potential of $-15.3 \mathrm{mV}$. The isoelectric point $(\mathrm{pI})$ of enzymes decides the surface electrical property of enzymes in solution. As we known, the pI of HRP ( $\mathrm{pI}=8.9$ [25]) is larger than $\mathrm{pH}$ 7.0. Hence, when $\mathrm{pH}$ (solution) $\leq 7.0$, the surface of HRP carries positive 
charge. Thus, positively charged HRP molecules in pH 7.0 PBS can be attached onto the3D$\mathrm{Bi}_{2} \mathrm{WO}_{6} \mathrm{MSs}$ surface by the electrostatic interaction.

UV-vis spectroscopy is an effective method to monitor the structure change of heme proteins. The Soret absorption bands of heme proteins provide information about the conformational integrity of the enzymes [26, 27]. As shown in Fig. 3, the Soret absorption band of HRP immobilized on Nafion/HRP/3D- $\mathrm{Bi}_{2} \mathrm{WO}_{6}$ (storage at $4{ }^{\circ} \mathrm{C}$ for four weeks) is located at $407 \mathrm{~nm}$ (curve a), which is close to that of native HRP at $409 \mathrm{~nm}$ (curve b), indicating that HRP retained the essential features of its conformational integrity. This reveals that Nafion/3D-Bi ${ }_{2} \mathrm{WO}_{6}$ composite film has biocompatibility and do not suffer significant enzymes denaturation.

\subsection{Direct electrochemistry behavior of Nafion/HRP/3D-Bi $2 \mathrm{WO}_{6} / \mathrm{GCE}$}

Fig. 4 depicts the typical cyclic voltammograms (CVs) of different modified electrodes in $0.1 \mathrm{M}$ PBS ( $\mathrm{pH} 7.0)$ at a scan rate of $0.1 \mathrm{~V} \mathrm{~s}^{-1}$. No redox peak is observed at Nafion/3D$\mathrm{Bi}_{2} \mathrm{WO}_{6} / \mathrm{GCE}$ (curve a), which indicates that Nafion/3D-Bi $\mathrm{WO}_{6} / \mathrm{GCE}$ is electroinactive in the potential window. The Nafion/HRP/3D- $\mathrm{Bi}_{2} \mathrm{WO}_{6} / \mathrm{GCE}$ (curve d) exhibits a couple of stable and well-defined redox peaks at $-0.367 \mathrm{~V}$ and $-0.323 \mathrm{~V}$ vs. $\mathrm{Ag} / \mathrm{AgCl}$, which could be ascribed to direct electron transfer between HRP and the underlying electrode. According to Li et al. [28], the electron transfer of HRP occurs between the $\mathrm{Fe}^{\mathrm{III}}$ and $\mathrm{Fe}^{\mathrm{II}}$ site within HRP. The formal potential $\left(\mathrm{E}^{0}=\left(\mathrm{E}_{\mathrm{p}, \mathrm{a}}+\mathrm{E}_{\mathrm{p}, \mathrm{c}}\right) / 2\right)$ of $\mathrm{HRP}$ is $-0.345 \mathrm{~V}$ vs. $\mathrm{Ag} / \mathrm{AgCl}$ is in agreement with $0.335 \mathrm{~V},-0.362 \mathrm{~V}$ and $-0.369 \mathrm{~V}$ vs. $\mathrm{Ag} / \mathrm{AgCl}$ reported for the $\mathrm{HRP}\left(\mathrm{Fe}^{\mathrm{III} / \mathrm{II}}\right)$ redox couple in HRP-ZrP, HRP-graphene-Nafion and HRP-GO-Nafion films [28-30]. The potential difference $\left(\Delta \mathrm{E}_{\mathrm{p}}\right)$ between the anodic and cathodic peak potential is about $44 \mathrm{mV}$.Such a small $\Delta \mathrm{E}_{\mathrm{p}}$ value reveals a fast and quasi-reversible electron-transfer process, and then indicates that the $3 \mathrm{D}-\mathrm{Bi}_{2} \mathrm{WO}_{6} \mathrm{MSs}$ can provide a favorable microenvironment for HRP to undergo a facile electron-transfer reaction. Compared with that of the Nafion/HRP/3D- $\mathrm{Bi}_{2} \mathrm{WO}_{6} / \mathrm{GCE}$, almost no redox peaks are observed at the Nafion/HRP/GCE (curve b, in Fig. 4), suggesting an enhanced electron transfer between HRP molecules and the surface of the Nafion/HRP/3D- 
$\mathrm{Bi}_{2} \mathrm{WO}_{6} / \mathrm{GCE}$. Meanwhile, due to the deep burying of electroactive center in the protein structure and the denaturation of proteins on the bare electrode surface, it is difficult for proteins to realize the DET process on the bare electrode [31]. It can be clearly seen from the comparison that direct electron transfer between HRP molecules and GCE is greatly enhanced at the Nafion/HRP/3D-Bi $2 \mathrm{WO}_{6} / \mathrm{GCE}$. For comparison, Nafion/HRP/Bi ${ }_{2} \mathrm{WO}_{6} \mathrm{NPs} / \mathrm{GCE}$ has also been carried out (curve c, in Fig. 4). The reduction peak of the electrode is $45.8 \%$ smaller than that of Nafion/HRP/3D- $\mathrm{Bi}_{2} \mathrm{WO}_{6} / \mathrm{GCE}$. The $\Delta \mathrm{E}_{\mathrm{p}}$ is $68 \mathrm{mV}$, which is larger than that of Nafion/HRP/3D-Bi $\mathrm{WO}_{6} / \mathrm{GCE}(44 \mathrm{mV})$, indicating faster electron transfer rate of $\mathrm{HRP}$ on the electrode than on Nafion/HRP/Bi $2 \mathrm{WO}_{6} \mathrm{NPs} / \mathrm{GCE}$. It can be concluded that $3 \mathrm{D}-\mathrm{Bi}_{2} \mathrm{WO}_{6} \mathrm{MSs}$ have better effect on the facilitation of electron transfer, which may result from unique morphology and property of the $3 \mathrm{D}-\mathrm{Bi}_{2} \mathrm{WO}_{6} \mathrm{MSs}$.

Fig. 5A shows the cyclic voltammograms of Nafion/HRP/3D- $\mathrm{Bi}_{2} \mathrm{WO}_{6} / \mathrm{GCE}$ at $0.1 \mathrm{M}$ PBS ( $\mathrm{pH}$ 7.0) with the scan rate increasing from 0.1 to $0.8 \mathrm{~V} \mathrm{~s}^{-1}$. With the increasing of the scan rate, the cathodic and anodic peak currents of HRP increase simultaneously. Meanwhile, the cathodic and anodic peak potentials show a slight shift respectively lead to the peak to peak separation slightly enlarged. Fig. 5B shows that the cathodic $\left(i_{p c}\right)$ and anodic $\left(i_{p a}\right)$ peak currents increase linearly with scan rates from 0.1 to $0.8 \mathrm{~V} \mathrm{~s}^{-1}$. This reveals that the electrode reaction corresponds to a surface-controlled quasi-reversible process. By using the Laviron method for a surface-controlled electrochemical system [29], the apparent heterogeneous electron transfer rate constant $\left(k_{s}\right)$ of $\mathrm{HRP}$ immobilized on Nafion/HRP/3D- $-\mathrm{Bi}_{2} \mathrm{WO}_{6} / \mathrm{GCE}$ is estimated to be about $3.4 \mathrm{~s}^{-1}$, which is higher than the value reported for HRP immobilized $\beta$ cyclodextrin hybrid film $\left(2.87 \mathrm{~s}^{-1}\right)$ [32], flowerlike ZnO-gold nanoparticle-Nafion nanocomposite $\left(1.94 \mathrm{~s}^{-1}\right)$ [33], suggesting a faster electron-transfer process. This means that the $3 \mathrm{D}-\mathrm{Bi}_{2} \mathrm{WO}_{6} \mathrm{MSs}$ facilitate the direct electron transfer of HRP. The average surface concentration of electroactive $\operatorname{HRP}\left(\Gamma^{*}, \mathrm{~mol} \mathrm{~cm}^{-2}\right)$ can be estimated from the charge integration of the reduction peak of the $\mathrm{CV}$ using the formula:

$$
Q=n F A \Gamma^{*}
$$


where F is Faraday constant, Q is the charge $(\mathrm{C})$ and can be obtained by integrating the reduction peak of HRP, $\mathrm{n}$ and $\mathrm{A}$ stand for the number of electron transferred and the geometrical surface area of the electrode, respectively. According to this method, the surface concentration of electroactive $\mathrm{HRP}\left(\Gamma^{*}\right)$ at Nafion/HRP/3D-Bi $\mathrm{WO}_{6} / \mathrm{GCE}$ is calculated as $1.13 \times 10^{-10} \mathrm{~mol} \mathrm{~cm}^{-2}$, which is much greater than the theoretical value for monolayer coverage $\left(1.89 \times 10^{-11} \mathrm{~mol} \mathrm{~cm} \mathrm{~cm}^{-2}\right)$ [34]. This means that multilayers of HRP entrapped in the Nafion/HRP/3D-Bi $2 \mathrm{WO}_{6} / \mathrm{GCE}$ participates in the electron-transfer process.

Fig. 6 shows the cyclic voltammograms of $0.1 \mathrm{M}$ PBS of different $\mathrm{pH}$ at a Nafion/HRP/3D$\mathrm{Bi}_{2} \mathrm{WO}_{6} / \mathrm{GCE}$. Stable and well-defined CVs are observed in the $\mathrm{pH}$ range 6.0 8.0. With the increasing of $\mathrm{pH}$ value, both the cathodic and anodic peaks shift to the negative (Fig. 6). This can be contributed to the involvement of proton transfer in the HRP(Fe $\left.e^{\mathrm{III}}\right) / \mathrm{HRP}\left(\mathrm{Fe}^{\mathrm{II}}\right)$ redox couple [35]. The $\mathrm{E}^{0^{\prime}}$ value of HRP varies linearly in the range of $\mathrm{pH}$ 6.0 8.0, with a slop of $52.5 \mathrm{mV} \mathrm{pH}^{-1}$ (the inset of Fig. 6). This value is very close to the theoretical value of the transfer of one proton and electron in a reversible reduction $\left(-58 \mathrm{mV} \mathrm{pH}^{-1}\right.$ at $\left.25^{\circ} \mathrm{C}\right)$ [36].

\subsection{Electrocatalytic properties of the Nafion/HRP/3D-Bi $2 \mathrm{WO}_{6} / \mathrm{GCE}$.}

By using $\mathrm{H}_{2} \mathrm{O}_{2}$ as a probe, the electrocatalytic properties of the Nafion/HRP/3D$\mathrm{Bi}_{2} \mathrm{WO}_{6} / \mathrm{GCE}$ were investigated. As shown in Fig. 7, the reduction peak increases dramatically with the addition of $\mathrm{H}_{2} \mathrm{O}_{2}$, accompanied by a decrease and disappearance of the oxidation peak, displaying the obvious electrocatalytic behavior of HRP for the reduction of $\mathrm{H}_{2} \mathrm{O}_{2}$ [27]. A possible reaction mechanism of $\mathrm{H}_{2} \mathrm{O}_{2}$ catalyzed by the HRP-based electrode is postulated as follows [28]:

$$
\begin{gathered}
\operatorname{HRP}\left(\mathrm{Fe}^{I I I}\right)+e^{-} \rightleftharpoons \operatorname{HRP}\left(\mathrm{Fe}^{I I}\right) \\
H R P\left(\mathrm{Fe}^{I I}\right)+\mathrm{H}_{2} \mathrm{O}_{2}+2 \mathrm{H}^{+} \rightarrow \operatorname{HRP}\left(\mathrm{Fe}^{I I I}\right)+2 \mathrm{H}_{2} \mathrm{O}
\end{gathered}
$$

With the $\mathrm{H}_{2} \mathrm{O}_{2}$ concentration increasing, the current value reaches a saturation limit (the inset of Fig. 7) and saturation behavior is characteristic of enzyme-based catalysis. The apparent Michaelis-Menten constant $\left(K_{M}^{a p p}\right)$ can be obtained by the electrochemical-version of Lineweaver-Burk equation [37] 


$$
\frac{1}{I_{s S}}=\frac{K_{M}^{a p p}}{I_{\max } C}+\frac{1}{I_{\max }}
$$

where $I_{s s}$ is the steady-state current after the addition of substrate, $C$ is the bulk concentration of the substrate, and $I_{\max }$ is the maximum current measured under saturated substrate conditions. The $K_{M}^{a p p}$ value for Nafion/HRP/3D- $\mathrm{Bi}_{2} \mathrm{WO}_{6} / \mathrm{GCE}$ is estimated to be $153 \mu \mathrm{M}$. This value is smaller than those ever reported values of $262 \mu \mathrm{M}$ [26] and $684 \mu \mathrm{M}$ [30], indicating that $\mathrm{HRP}$ immobilized on Nafion/HRP/3D- $\mathrm{Bi}_{2} \mathrm{WO}_{6} / \mathrm{GCE}$ retains higher bioactivity.

\subsection{Biosensor performance of the Nafion/HRP/3D- $\mathrm{Bi}_{2} \mathrm{WO}_{6} / \mathrm{GCE}$}

The biosensor performance for the detection of $\mathrm{H}_{2} \mathrm{O}_{2}$ of the Nafion/HRP/3D- $\mathrm{Bi}_{2} \mathrm{WO}_{6} / \mathrm{GCE}$ was also investigated by amperometry. Fig. 8 gives the amperometric responses of the modified glassy carbon electrodes at $-0.35 \mathrm{~V}$ after adding $\mathrm{H}_{2} \mathrm{O}_{2}$ in stirred PBS (pH 7.0). Fig. $8 \mathrm{~A}$ demonstrates that, on Nafion/HRP/3D- $\mathrm{Bi}_{2} \mathrm{WO}_{6} / \mathrm{GCE}$, the response time (achieving $95 \%$ of the steady-state current) is less than $3 \mathrm{~s}$. Fig. $8 \mathrm{~B}$ shows two linear sections in the calibration plots. The first section is from 0.5 to $100 \mu \mathrm{M}$ with a correlation coefficient of $0.9983(\mathrm{~N}=14)$, and the other is from 100 to $250 \mu \mathrm{M}$ with a correlation coefficient of $0.9987(\mathrm{~N}=16)$. The method detection limit is estimated to be $0.18 \mu \mathrm{M}$ (the signal to noise ratio is 3 ). Performances of various $\mathrm{H}_{2} \mathrm{O}_{2}$ biosensors are listed in Table S1. It is clear that the performance of Nafion/HRP/3D- $\mathrm{Bi}_{2} \mathrm{WO}_{6} / \mathrm{GCE}$ is significantly improved. Furthermore, compared with Nafion/HRP/Bi $2 \mathrm{WO}_{6} \mathrm{NPs} / \mathrm{GCE}$, the $3 \mathrm{D}-\mathrm{Bi}_{2} \mathrm{WO}_{6}$ based biosensor has better performance (Fig. S2). There are some reasons why the Nafion/HRP/3D-Bi $\mathrm{WO}_{6} / \mathrm{GCE}$ displays both a lower method detection limit and a wider linear range. Firstly, this kind of three-dimensional flower-like $\mathrm{Bi}_{2} \mathrm{WO}_{6}$ microspheres can greatly enhance the active surface area for enzymes' adsorption. More importantly, the substrate can simply be entrapped by $3 \mathrm{D}-\mathrm{Bi}_{2} \mathrm{WO}_{6} \mathrm{MSs}$ with larger specific surface area and the special flower-like structure, and have easy access to the enzymes immobilized on the surface of $3 \mathrm{D}-\mathrm{Bi}_{2} \mathrm{WO}_{6} \mathrm{MSs}$. There is an increased chance of effective collisions between substrate and redox protein leading to improved performance of this sensor [24]. 


\subsection{Stability and reproducibility of the biosensor}

The long-term stability of the fabricated biosensors was studied by examining its current response after storage at $4{ }^{\circ} \mathrm{C}$. The biosensors can retain $93.1 \%$ of the initial response to $\mathrm{H}_{2} \mathrm{O}_{2}$ after 30-day storage, demonstrating good long-term stability (Fig. S3). The good long-term stability can be contributed to the good biocompatibility of $3 \mathrm{D}^{-\mathrm{Bi}_{2}} \mathrm{WO}_{6} \mathrm{MSs}$ which can provide a favorable microenvironment for HRP to retain its bioactivity.

The reproducibility of the biosensor was investigated by determining $5 \mu \mathrm{M} \mathrm{H}_{2} \mathrm{O}_{2}$ in PBS ( $\mathrm{pH}$ 7.0). The relative standard deviation (R.S.D) is $3.2 \%$ for 5 successive measurements. Five biosensors prepared under the same conditions independently give a R.S.D. of $3.8 \%$ for the determination of $5 \mu \mathrm{M} \mathrm{H}_{2} \mathrm{O}_{2}$ in PBS (0.1 M, pH 7.0), indicating an acceptable electrodeto-electrode reproducibility.

\subsection{Analysis of real samples}

In order to evaluate the analytical utility of the electrode in practice, the Nafion/HRP/3D$\mathrm{Bi}_{2} \mathrm{WO}_{6} / \mathrm{GCE}$ is applied for determination of real contact lens care solution. Before experiments, the real samples are diluted 5000 times with doubly distilled water and without any other pretreatments. Recovery tests and $\mathrm{KMnO}_{4}$ titration method were used to examine the reliability and accuracy of this method. The $\mathrm{H}_{2} \mathrm{O}_{2}$ content of different samples and recoveries of added analyte are evaluated, and the results confirm that determining the $\mathrm{H}_{2} \mathrm{O}_{2}$ concentration in real samples by using the proposed method is reliable (Table 1)."

\section{Conclusion}

In summary, three-dimensional flower-like $\mathrm{Bi}_{2} \mathrm{WO}_{6}$ microspheres have been synthesized through a simple hydrothermal method and subsequently are used to fabricate a mediator-free biosensor for the detection of $\mathrm{H}_{2} \mathrm{O}_{2}$. Due to unique morphology of the flower-like microspheres, the Nafion/HRP/3D- $\mathrm{Bi}_{2} \mathrm{WO}_{6} / \mathrm{GCE}$ biosensor displays a low method detection limit of $0.18 \mu \mathrm{M}$ and a wide linear range from 0.5 to $250 \mu \mathrm{M}$ for $\mathrm{H}_{2} \mathrm{O}_{2}$. 


\section{Acknowledgments}

This work was financially supported by the National Science Foundation of China (51272147), the Academic Backbone Cultivation Program of Shaanxi University of Science \& Technology (XSGP201203) and the Graduate Innovation Fund of Shaanxi University of Science and Technology. 


\section{References}

[1] H. Beitollahi, M.M. Ardakani, B. Ganjipour, H. Naeimi, Biosensors and Bioelectronics 24 (2008) 362-368.

[2] H. Hosseini, M. Behbahani, M. Mahyari, H. Kazerooni, A. Bagheri, A. Shaabani, Biosensors and Bioelectronics 59 (2014) 412-417.

[3] M.K. Bojdi, M.H. Mashhadizadeh, M. Behbahani, A. Farahani, S.S.H. Davarani, A. Bagheri, Electrochimica Acta 136 (2014) 59-65.

[4] M.K. Bojdi, M. Behbahani, M.H. Mashhadizadeh, A. Bagheri, S.S.H. Davarani, A. Farahani, Materials Science and Engineering: C 48 (2015) 213-219.

[5] E. Molaakbari, A. Mostafavi, H. Beitollahi, R. Alizadeh, Analyst 139 (2014) 4356-4364.

[6] H. Beitollahi, H. Karimi-Maleh, H. Khabazzadeh, Analytical Chemistry 80 (2008) 98489851.

[7] H. Beitollahi, I. Sheikhshoaie, Electrochimica Acta 56 (2011) 10259-10263.

[8] H. Beitollahi, I. Sheikhshoaie, Journal of Electroanalytical Chemistry 661 (2011) 336-342.

[9] M. Baghayeri, H. Veisi, Biosensors and Bioelectronics 74 (2015) 190-198.

[10] M. Baghayeri, E.N. Zare, M.M. Lakouraj, Biosensors and Bioelectronics 55 (2014) 259265.

[11] M. Baghayeri, E.N. Zare, R. Hasanzadeh, Materials Science and Engineering: C 39 (2014) 213-220.

[12] M. Baghayeri, RSC Advances 5 (2015) 18267-18274.

[13] M. Baghayeri, H. Veisi, H. Veisi, B. Maleki, H. Karimi-Maleh, H. Beitollahi, RSC Advances 4 (2014) 49595-49604.

[14] M. Baghayeri, E.N. Zare, M.M. Lakouraj, Sensors and Actuators B: Chemical 202 (2014) 1200-1208.

[15] C. Léger, S.J. Elliott, K.R. Hoke, L.J. Jeuken, A.K. Jones, F.A. Armstrong, Biochemistry 42 (2003) 8653-8662. 
[16] I. Hamachi, A. Fujita, T. Kunitake, Journal of the American Chemical Society 119 (1997) 9096-9102.

[17] Z. Zhu, L. Qu, Q. Niu, Y. Zeng, W. Sun, X. Huang, Biosensors and Bioelectronics 26 (2011) 2119-2124.

[18] Q.-L. Sheng, J.-B. Zheng, X.-D. Shang-Guan, W.-H. Lin, Y.-Y. Li, R.-X. Liu, Electrochimica Acta 55 (2010) 3185-3191.

[19] S. Dong, P. Zhang, H. Liu, N. Li, T. Huang, Biosensors and Bioelectronics 26 (2011) 4082-4087.

[20] X. Lu, H. Zhang, Y. Ni, Q. Zhang, J. Chen, Biosensors and bioelectronics 24 (2008) 9398.

[21] H. Tao, J. Wang, Y. Ou, W. Zhu, H. Ling, W. Fang, D. Tu, Nanoscience and Nanotechnology Letters 6 (2014) 99-105.

[22] Q. Xie, X. Chen, H. Liu, W. Yang, Sensors and Actuators B: Chemical 168 (2012) 277282.

[23] J. Kim, J.W. Grate, P. Wang, Chemical engineering science 61 (2006) 1017-1026.

[24] Q. Xie, Y. Zhao, X. Chen, H. Liu, D.G. Evans, W. Yang, Biomaterials 32 (2011) 65886594.

[25] G.-X. Wang, W.-J. Bao, J. Wang, Q.-Q. Lu, X.-H. Xia, Electrochemistry Communications 35 (2013) 146-148.

[26] X. Chen, C. Fu, Y. Wang, W. Yang, D.G. Evans, Biosensors and Bioelectronics 24 (2008) 356-361.

[27] S. Mao, Y. Long, W. Li, Y. Tu, A. Deng, Biosensors and Bioelectronics 48 (2013) 258262.

[28] M. Li, S. Xu, M. Tang, L. Liu, F. Gao, Y. Wang, Electrochimica Acta 56 (2011) 11441149.

[29] X. Yang, X. Chen, L. Yang, W. Yang, Bioelectrochemistry 74 (2008) 90-95.

[30] L. Zhang, H. Cheng, H.-m. Zhang, L. Qu, Electrochimica Acta 65 (2012) 122-126. 
[31] H. Liu, C. Duan, C. Yang, X. Chen, W. Shen, Z. Zhu, Materials Science and Engineering: C $53(2015)$ 43-49.

[32] A. Cao, H. Ai, Y. Ding, C. Dai, J. Fei, Sensors and Actuators B: Chemical 155 (2011) $632-638$.

[33] C. Xiang, Y. Zou, L.-X. Sun, F. Xu, Sensors and Actuators B: Chemical 136 (2009) 158162.

[34] S.-F. Wang, T. Chen, Z.-L. Zhang, X.-C. Shen, Z.-X. Lu, D.-W. Pang, K.-Y. Wong, Langmuir 21 (2005) 9260-9266.

[35] X. Chen, Q. Wang, L. Wang, F. Gao, W. Wang, Z. Hu, Biosensors and Bioelectronics 66 (2015) 216-223.

[36] F. Wu, J. Xu, Y. Tian, Z. Hu, L. Wang, Y. Xian, L. Jin, Biosensors and Bioelectronics 24 (2008) 198-203.

[37] R.A. Kamin, G.S. Wilson, Analytical Chemistry 52 (1980) 1198-1205. 


\section{Figure Captions:}

Scheme 1 Schematic illustration of the $3 \mathrm{D}-\mathrm{Bi}_{2} \mathrm{WO}_{6} \mathrm{MSs}$ immobilizing HRP.

Fig. 1 XRD pattern of the $3 \mathrm{D}-\mathrm{Bi}_{2} \mathrm{WO}_{6} \mathrm{MSs}$.

Fig 2. SEM images of typical as-synthesized $3 \mathrm{D}-\mathrm{Bi}_{2} \mathrm{WO}_{6} \mathrm{MSs}(\mathrm{A}$ and $\mathrm{B}$ ) and Nafion/HRP/3D-Bi ${ }_{2} \mathrm{WO}_{6}$ composite film (C and D).

Fig. 3 UV-vis spectra of Nafion/HRP/3D-Bi ${ }_{2} \mathrm{WO}_{6}$ composite film (a) and HRP (b).

Fig. 4 Cyclic voltammograms of Nafion/3D- $\mathrm{Bi}_{2} \mathrm{WO}_{6} / \mathrm{GCE}$ (a), Nafion/HRP/GCE (b), Nafion/HRP/Bi ${ }_{2} \mathrm{WO}_{6} \mathrm{NPs} / \mathrm{GCE}$ (c), Nafion/HRP/3D-Bi ${ }_{2} \mathrm{WO}_{6} / \mathrm{GCE}(\mathrm{d})$, in $0.1 \mathrm{M} \mathrm{pH} 7.0$ PBS with a scan rate of $0.1 \mathrm{~V} \mathrm{~s}^{-1}$.

Fig. $5 \mathrm{CVs}$ of Nafion/HRP/3D-Bi $2 \mathrm{WO}_{6} / \mathrm{GCE}$ in $0.1 \mathrm{M} \mathrm{pH}$ 7.0 PBS with increasing scan rates from 0.1 to $0.8 \mathrm{Vs}^{-1}$ (A), plot of cathodic and anodic peak current vs. scan rate (B).

Fig. 6 Cyclic voltammograms of Nafion/HRP/3D-Bi $\mathrm{WO}_{6} / \mathrm{GCE}$ in $0.1 \mathrm{M}$ PBS with different $\mathrm{pH}$ values from 6 to 8. Inset: plot of cathodic and anodic peak current vs. $\mathrm{pH}$ values.

Fig. $7 \mathrm{CVs}$ of the Nafion/HRP/3D- $\mathrm{Bi}_{2} \mathrm{WO}_{6} / \mathrm{GCE}$ in $0.1 \mathrm{M} \mathrm{pH} 7.0 \mathrm{PBS}$ containing 0 (a), 10 (b), 30 (c), 50 (d), 70 (e), 110 (f), 150 (g), 190 (h), 230 (i) $\mu \mathrm{M} \mathrm{H}_{2} \mathrm{O}_{2}$ at a scan rate of $\mathrm{v}=0.1$ $\mathrm{V} \mathrm{s}^{-1}$. Inset: plot of the relationship between catalytic reduction current and the concentration of $\mathrm{H}_{2} \mathrm{O}_{2}$.

Fig. 8 Amperometric response curves of the Nafion/HRP/3D- $\mathrm{Bi}_{2} \mathrm{WO}_{6} / \mathrm{GCE}$ to $\mathrm{H}_{2} \mathrm{O}_{2}$. Applied potential: $-0.35 \mathrm{~V}(\mathrm{~A})$. Plot of steady-state response currents against concentrations of $\mathrm{H}_{2} \mathrm{O}_{2}(\mathrm{~B})$.

Table 1 Determination results of $\mathrm{H}_{2} \mathrm{O}_{2}$ in real samples. 
Scheme 1

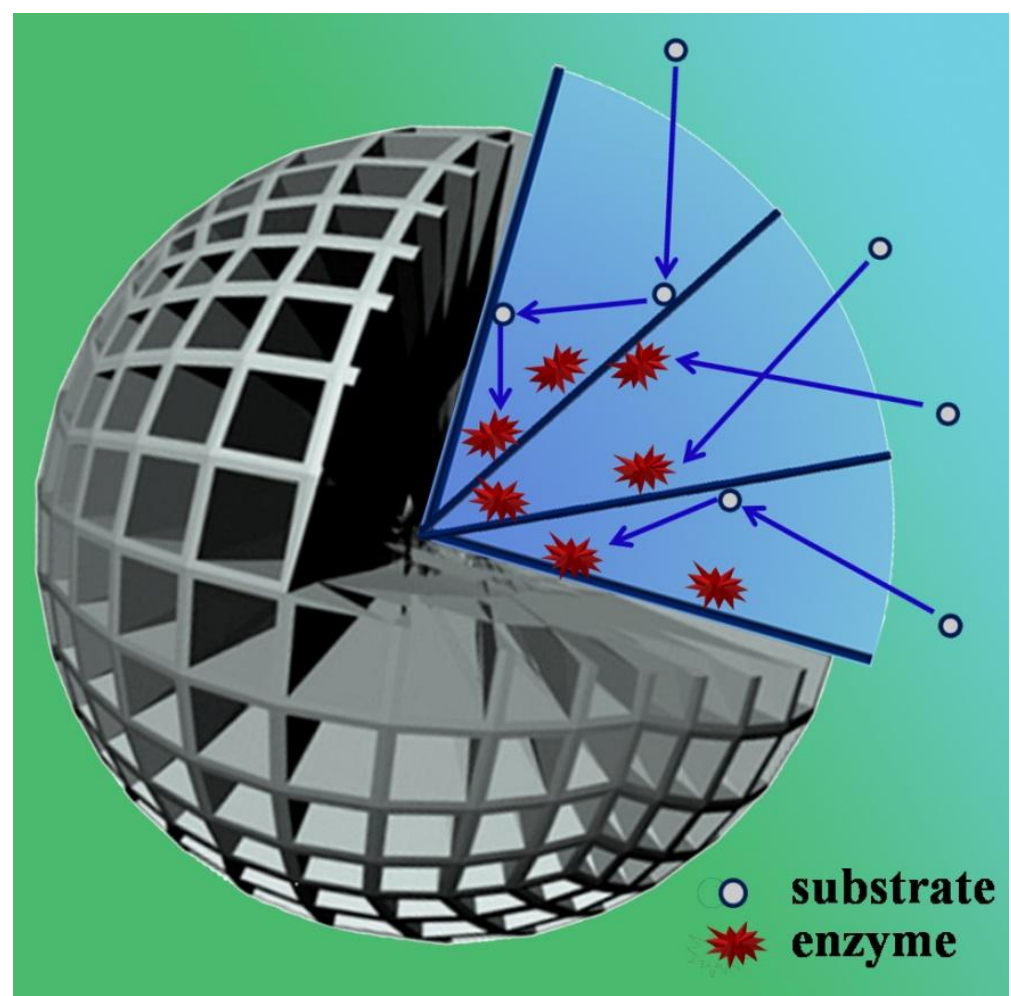

Scheme 1 Schematic illustration of the $3 \mathrm{D}-\mathrm{Bi}_{2} \mathrm{WO}_{6} \mathrm{MSs}$ immobilizing HRP. 
Figure 1

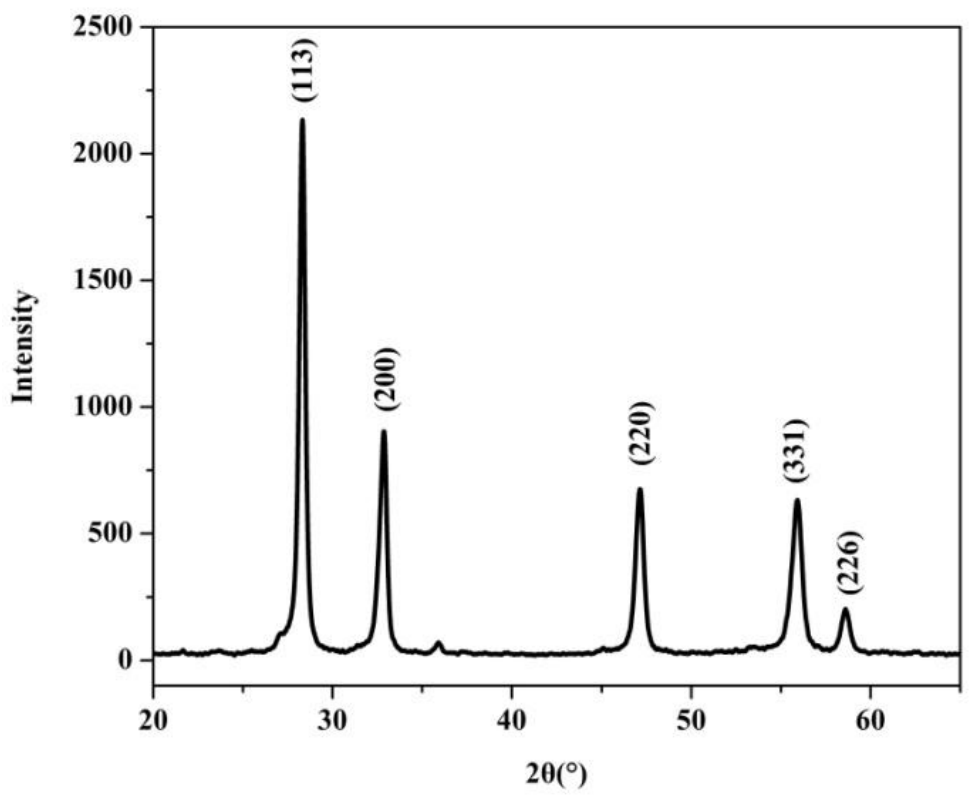

Fig. 1 XRD pattern of the $3 \mathrm{D}-\mathrm{Bi}_{2} \mathrm{WO}_{6} \mathrm{MSs}$. 


\section{Figure 2}

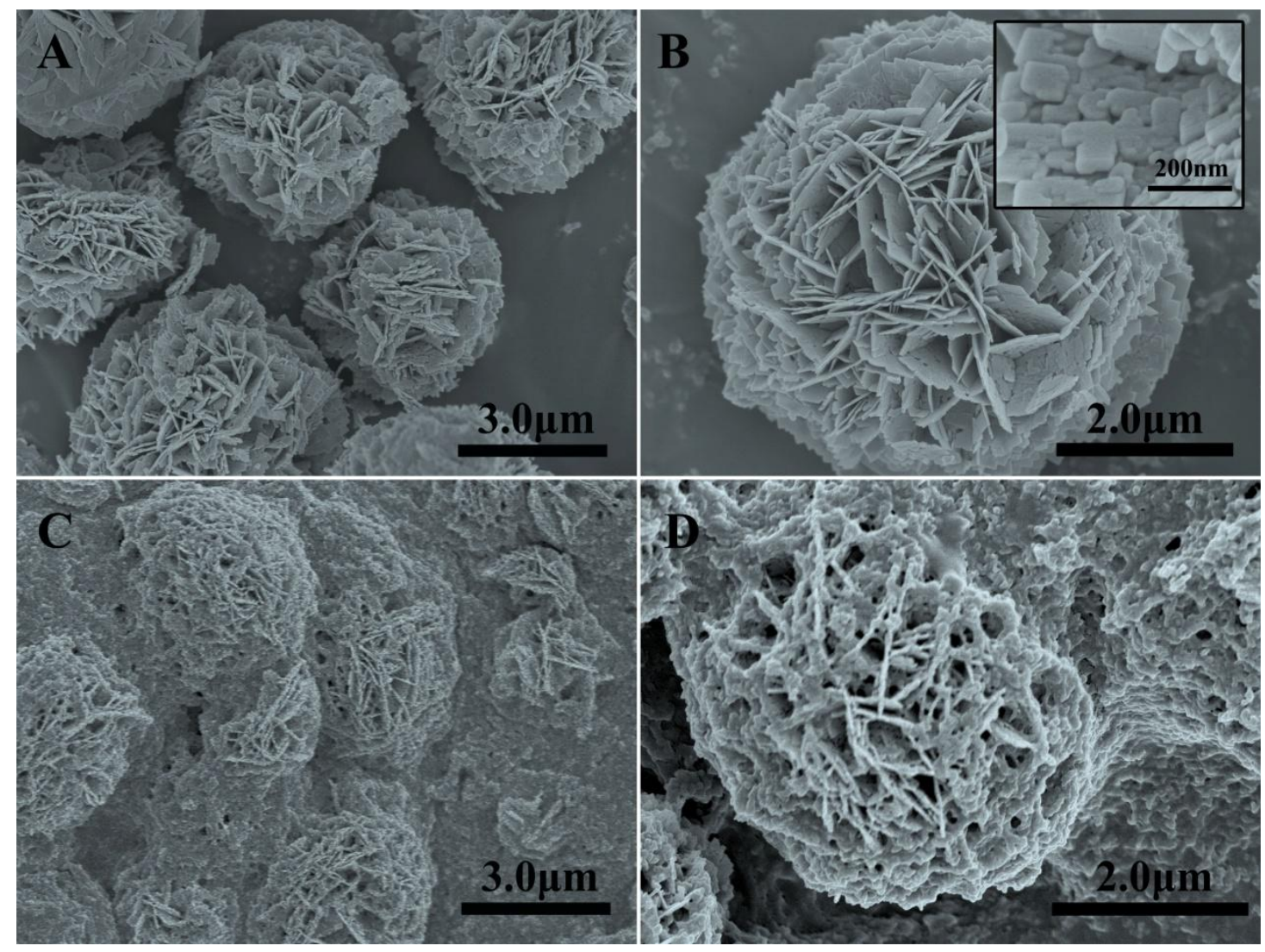

Fig 2. SEM images of typical as-synthesized $3 \mathrm{D}-\mathrm{Bi}_{2} \mathrm{WO}_{6} \mathrm{MSs}(\mathrm{A}$ and $\mathrm{B})$ and

Nafion/HRP/3D-Bi ${ }_{2} \mathrm{WO}_{6}$ composite film (C and D). 
Figure 3

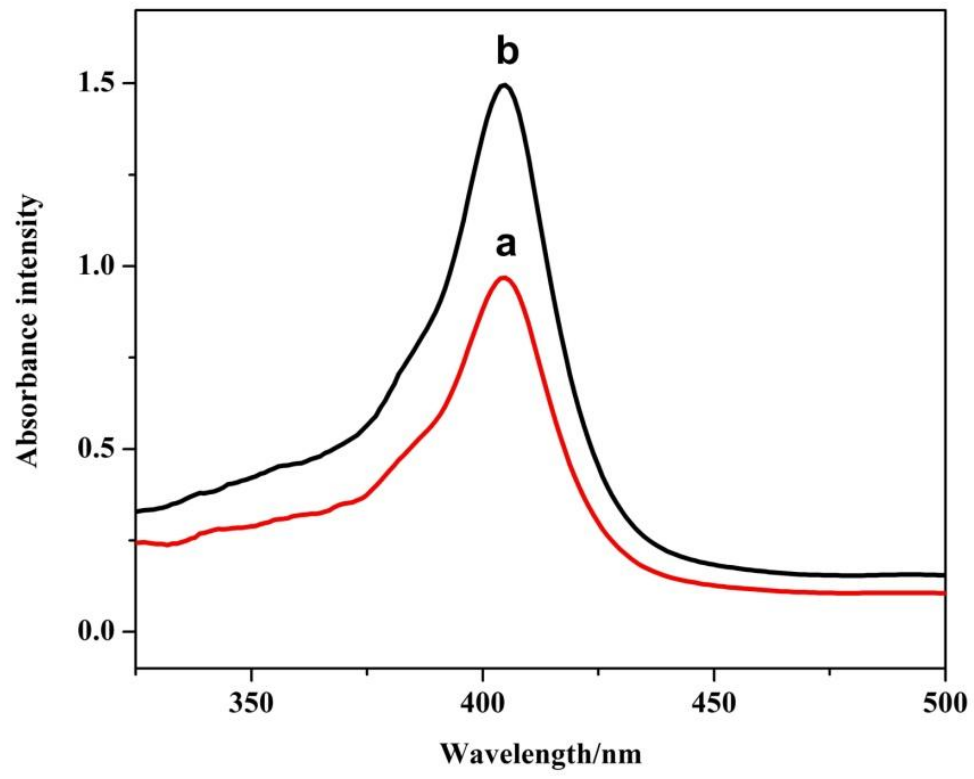

Fig. 3 UV-vis spectra of Nafion/HRP/3D-Bi $\mathrm{WO}_{6}$ composite film (a) and HRP (b). 
Figure 4

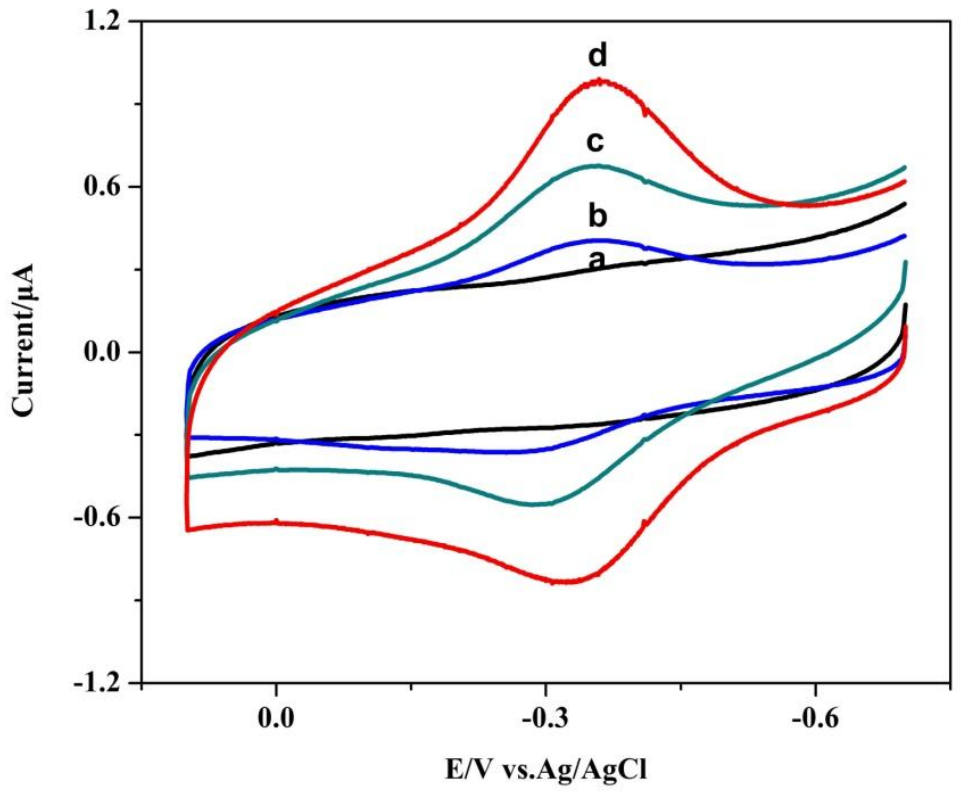

Fig. 4 Cyclic voltammograms of Nafion/3D-Bi ${ }_{2} \mathrm{WO}_{6} / \mathrm{GCE}$ (a), Nafion/HRP/GCE (b), Nafion/HRP/Bi $2 \mathrm{WO}_{6} \mathrm{NPs} / \mathrm{GCE}$ (c), Nafion/HRP/3D-Bi $\mathrm{WO}_{6} / \mathrm{GCE}$ (d), in $0.1 \mathrm{M}$ pH $7.0 \mathrm{PBS}$ with a scan rate of $0.1 \mathrm{~V} \mathrm{~s}^{-1}$. 
Figure 5
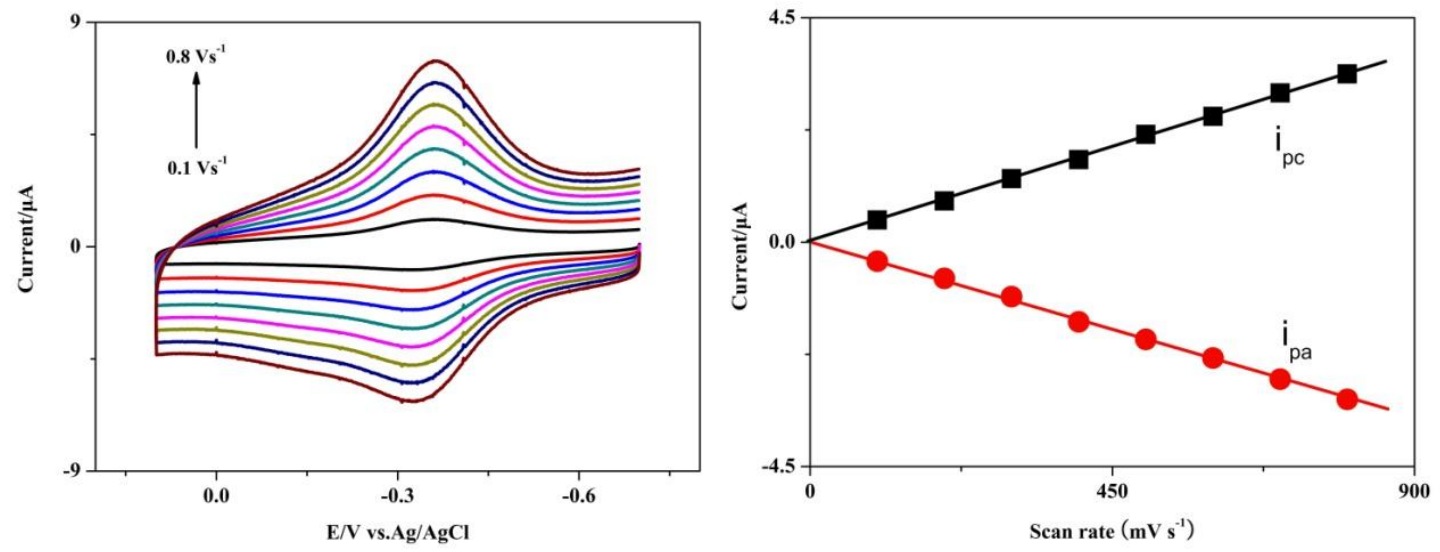

Fig. 5 Cyclic voltammograms of Nafion/HRP/3D- $\mathrm{Bi}_{2} \mathrm{WO}_{6} / \mathrm{GCE}$ in $0.1 \mathrm{M}$ pH 7.0 PBS with increasing scan rates from 0.1 to $0.8 \mathrm{Vs}^{-1}$ (A), plot of cathodic and anodic peak current vs. scan rate $(\mathrm{B})$. 


\section{Figure 6}

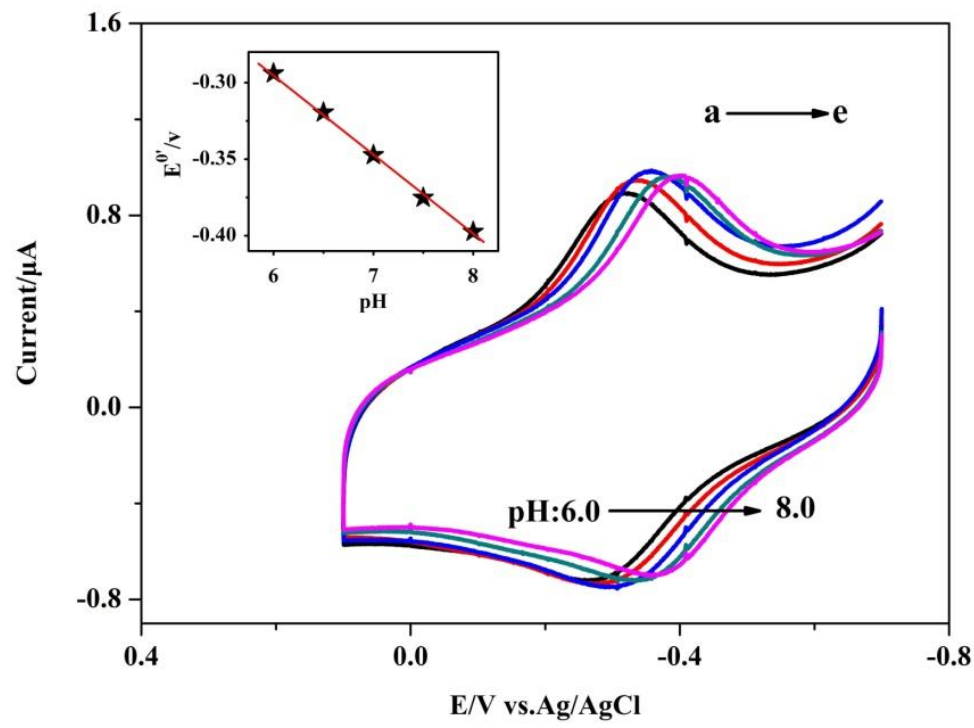

Fig. 6 Cyclic voltammograms of Nafion/HRP/3D- $\mathrm{Bi}_{2} \mathrm{WO}_{6} / \mathrm{GCE}$ in $0.1 \mathrm{M} \mathrm{PBS}$ with different $\mathrm{pH}$ values from 6 to 8. Inset: plot of cathodic and anodic peak current vs. pH values. 


\section{Figure 7}

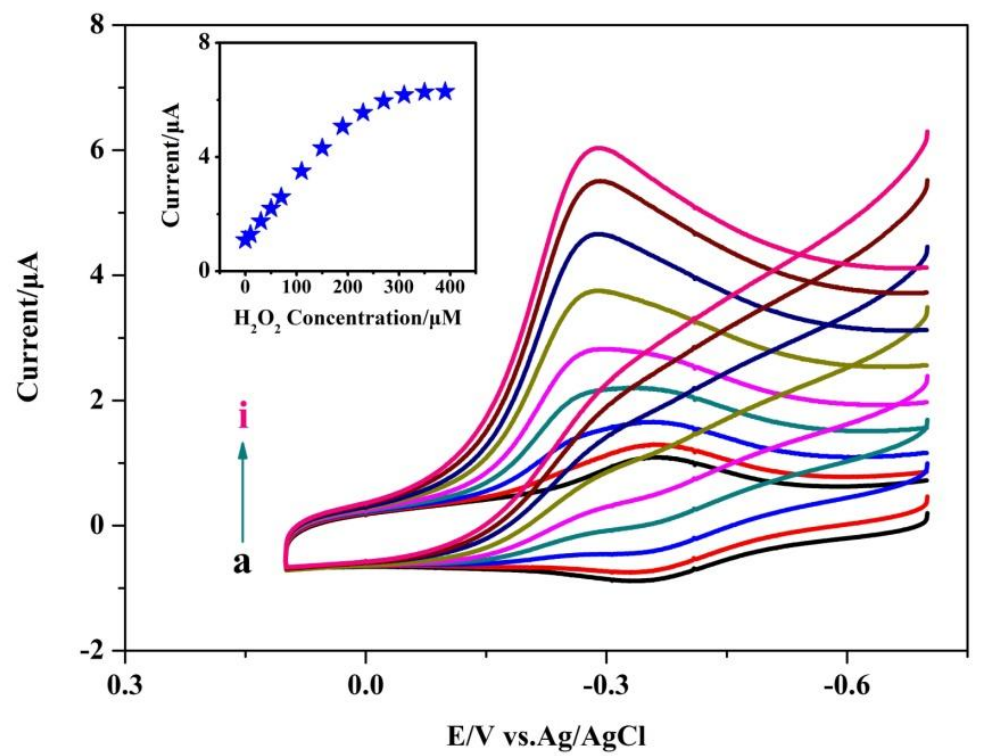

Fig. 7 Cyclic voltammograms of the Nafion/HRP/3D-Bi $\mathrm{WO}_{6} / \mathrm{GCE}$ in $0.1 \mathrm{M} \mathrm{pH} 7.0 \mathrm{PBS}$ containing 0 (a), 10 (b), 30 (c), 50 (d), 70 (e), 110 (f), 150 (g), 190 (h), 230 (i) $\mu \mathrm{M} \mathrm{H}_{2} \mathrm{O}_{2}$ at a scan rate of $\mathrm{v}=0.1 \mathrm{~V} \mathrm{~s}^{-1}$. Inset: plot of the relationship between catalytic reduction current and the concentration of $\mathrm{H}_{2} \mathrm{O}_{2}$. 
Figure 8
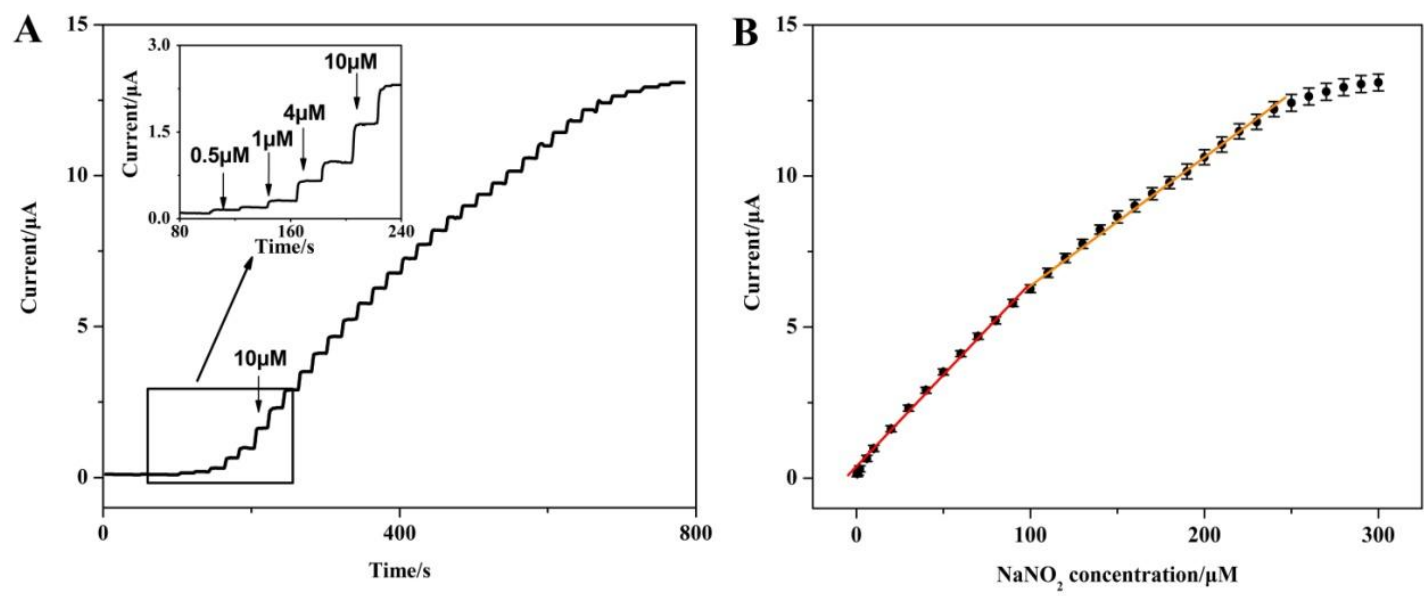

Fig. 8 Amperometric response curves of the Nafion/HRP/3D- $\mathrm{Bi}_{2} \mathrm{WO}_{6} / \mathrm{GCE}$ to $\mathrm{H}_{2} \mathrm{O}_{2}$. Applied potential: $-0.35 \mathrm{~V}$ (A). Plot of steady-state response currents against concentrations of $\mathrm{H}_{2} \mathrm{O}_{2}(B)$. 
Table 1 Determination results of $\mathrm{H}_{2} \mathrm{O}_{2}$ in real samples

\begin{tabular}{cccccc}
\hline Samples & $\begin{array}{c}\mathrm{KMnO}_{4} \\
\text { titration }(\mathrm{mM})\end{array}$ & $\begin{array}{c}\text { This work } \\
(\mathrm{mM})\end{array}$ & $\begin{array}{c}\text { Added } \\
(\mathrm{mM})^{\mathrm{a}}\end{array}$ & $\begin{array}{c}\text { Found } \\
(\mathrm{mM})^{\mathrm{b}}\end{array}$ & \begin{tabular}{c} 
Recovery (\%) \\
\hline 1
\end{tabular} \\
\hline 0.17 & 0.17 & 0.10 & 0.26 & 96.3 \\
3 & 0.13 & 0.14 & 0.10 & 0.25 & 96.1 \\
\hline
\end{tabular}

${ }^{\mathrm{a}}$ Standard $\mathrm{H}_{2} \mathrm{O}_{2}$ solution added to the samples.

${ }^{b}$ The total concentrations of $\mathrm{H}_{2} \mathrm{O}_{2}$ after addition of standard $\mathrm{H}_{2} \mathrm{O}_{2}$ solution to the samples. 


\section{Graphical abstract}

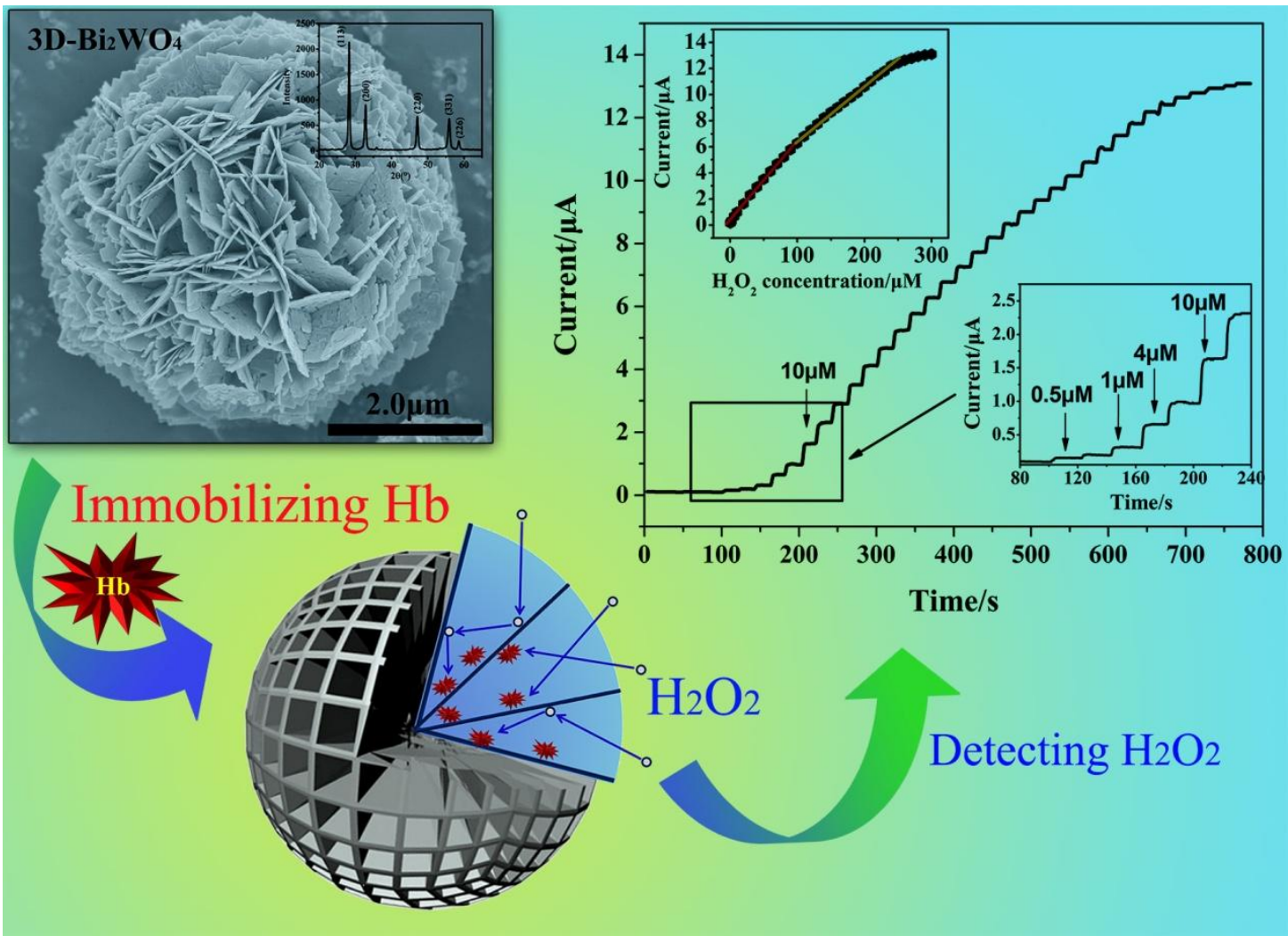

